\title{
Werk, werkloosheid en het vacuum tussen burger en gemeente
}

Citation for published version (APA):

Romme, A. (1997). Werk, werkloosheid en het vacuum tussen burger en gemeente. NIBOR, Netherlands Institute of Business Organization and Strategy Research. NIBOR Research Memorandum No. 02 https://doi.org/10.26481/umanib.1997002

Document status and date:

Published: 01/01/1997

DOI:

10.26481/umanib.1997002

Document Version:

Publisher's PDF, also known as Version of record

\section{Please check the document version of this publication:}

- A submitted manuscript is the version of the article upon submission and before peer-review. There can be important differences between the submitted version and the official published version of record.

People interested in the research are advised to contact the author for the final version of the publication, or visit the DOI to the publisher's website.

- The final author version and the galley proof are versions of the publication after peer review.

- The final published version features the final layout of the paper including the volume, issue and page numbers.

Link to publication

\footnotetext{
General rights rights.

- You may freely distribute the URL identifying the publication in the public portal. please follow below link for the End User Agreement:

www.umlib.nl/taverne-license

Take down policy

If you believe that this document breaches copyright please contact us at:

repository@maastrichtuniversity.nl

providing details and we will investigate your claim.
}

Copyright and moral rights for the publications made accessible in the public portal are retained by the authors and/or other copyright owners and it is a condition of accessing publications that users recognise and abide by the legal requirements associated with these

- Users may download and print one copy of any publication from the public portal for the purpose of private study or research.

- You may not further distribute the material or use it for any profit-making activity or commercial gain

If the publication is distributed under the terms of Article $25 \mathrm{fa}$ of the Dutch Copyright Act, indicated by the "Taverne" license above, 
Werk, werkloosheid en het vacuüm tussen burger en gemeente

Sj. Romme

$\mathrm{NIBOR} / \mathrm{RM} / 97 / 02$

http://www.unimaas.nl/ document/fdewb.htm

J.E.Lit. code: O17

$n i b o r$

Netherlands Institute of

Business Organization

and Strategy Research

University of Maastricht

Faculty of Economics and Business Administration

P.O. Box 616

6200 MD Maastricht

The Netherlands

Phone: ++3143 - 3883805 
Fax : ++3143-3258495

WERK, WERKLOOSHEID EN HET VACUÜM TUSSEN BURGER EN GEMEENTE

\author{
Sjoerd Romme \\ Universiteit Maastricht \\ Faculteit der Economische Wetenschappen \& Bedrijfskunde \\ vakgroep Managementwetenschappen \\ Postbus 616, 6200 MD Maastricht
}




\section{WERK, WERKLOOSHEID EN HET VACUÜM TUSSEN BURGER EN GEMEENTE}

\section{Samenvatting}

Werkloosheid vormt een van de grootste problemen van de westerse samenleving, maar is tegelijkertijd moeilijk met behulp van theorieën te verklaren. Dit artikel behandelt in dit verband de noodzaak tot institutionele vernieuwing in buurten, wijken en eventueel deelgemeenten. De volgende vraag staat hierbij centraal: wat is de mogelijke bijdrage van de kringorganisatiemethode aan de analyse en mogelijke oplossing van het werkloosheidsvraagstuk? In het kader van deze vraag worden de mogelijkheden onderzocht om de lokale institutionele infrastructuur te vernieuwen met behulp van de principes van kringorganiseren die zijn ontwikkeld door de Rotterdamse ingenieur Gerard Endenburg. Deze benadering is met name interessant omdat het huidige werkgelegenheidsbeleid is gebaseerd op de veronderstelling dat er ontwerpfouten in de relatie tussen de markteconomie en het sociale zekerheidssysteem zitten, waardoor de afstemming tussen vraag en aanbod op de arbeidsmarkt verstoord raakt. Een gedetailleerde analyse van deze ontwerpfouten ontbreekt echter in de literatuur, waardoor ook beleid gericht op het herstellen van deze dieperliggende oorzaak van het werkloosheidsprobleem achterwege blijt.

We bespreken eerst het huidige werkgelegenheidsbeleid van het kabinet Kok. Daarna worden de begrippen 'werk' en 'werkloosheid' in een historisch perspectief geplaatst. Vervolgens gaan we na hoe diverse ontwikkelingen de scheiding tussen werk en werkloosheid, en daarmee samenhangende scheiding tussen werk- en niet-werksfeer, ondermijnen. Deze problematiek hangt nauw samen met het ontstaan van een zogenaamd institutioneel vacuüm tussen individuele burger en gemeente, waardoor op dit niveau een dynamische sociaal-politieke structuur ontbreekt. Dit vacuüm kan worden gezien als een fundamentele constructiefout van de westerse samenleving die zichtbaar wordt in het probleem van structurele werkloosheid. De principes van kringorganiseren kunnen worden gebruikt om genoemd vacuüm in te vullen. Deze weg van lokale institutionele vernieuwing is in hoge mate complementair aan het werkgelegenheidsbeleid van de huidige regering. 


\section{Inleiding}

Werkloosheid wordt op dit moment algemeen beschouwd als een van de grootste problemen van de westerse samenleving. Het kabinet Kok heeft destijds in zijn regeerakkoord het tekort aan werkgelegenheid zelfs als zijn grootste zorg bestempeld. Tegelijkertijd ervaren wetenschappelijk onderzoekers het werkloosheidsvraagstuk als een complex probleem dat niet of nauwelijks met behulp van bestaande theorieën is te verklaren, laat staan met behulp van op deze theorieën gebaseerd beleid is te bestrijden (Freeman, 1995; Lindbeck, 1994; Pen, 1992).

Het is derhalve niet verwonderlijk dat het beleid van rijks-, regionale en gemeentelijke overheidsinstanties weinig doeltreffend lijkt te zijn wat betreft een structurele vermindering van de werkloosheid. Het volume van zowel de geregistreerde als de verborgen werkloosheid in ondermeer de WAO en VUT is des te opvallender omdat er meer dan genoeg "werk" te doen is, in de zin van het vervullen van behoeften. Onder beleidsmakers, politici en onderzoekers groeit derhalve het besef dat werk meer is dan vaste, duidelijk omschreven banen. Bovendien stellen steeds meer waarnemers vast dat institutionele vernieuwing van de (Nederlandse) welvaartstaat een noodzakelijke voorwaarde is voor een fundamentele aanpak van het werkloosheidsvraagstuk (Freeman, 1995; Glebbeek, 1996; Lindbeck, 1994; Weitzman, 1984; Wijvekate en Wijvekate, 1983).

Dit artikel behandelt de mogelijkheden voor lokale institutionele vernieuwing in buurten, wijken en eventueel deelgemeenten. De volgende vraag staat hierbij centraal: wat is de mogelijke bijdrage van de kringorganisatiemethode aan de analyse en mogelijke oplossing van het werkloosheidsvraagstuk? In het kader van deze vraag bespreken we de mogelijkheden tot vernieuwing van de lokale institutionele infrastructuur aan de hand van principes van kringorganiseren, ook wel bekend als de sociocratische organisatiemethode die is ontwikkeld door de Rotterdamse ingenieur Gerard Endenburg (1981; 1992). Deze methode is met name interessant omdat het huidige werkgelegenheidsbeleid is gebaseerd op de veronderstelling dat er ontwerpfouten in de relatie tussen de markteconomie en het sociale zekerheidssysteem zitten, waardoor de afstemming tussen vraag en aanbod op de arbeidsmarkt verstoord raakt (Freeman, 1995; Glebbeek, 1996; Pen, 1992). Een gedetailleerde analyse van deze ontwerpfouten ontbreekt echter in de literatuur. Op dit punt kunnen de principes van kringorganiseren, die zijn ontleend aan de dynamische systeemtheorie ofwel systeemdynamica (Romme, 1995), een interessante bijdrage aan de analyse en beleidsvorming ten aanzien van werkloosheid leveren.

Het betoog is als volgt opgebouwd. We bespreken eerst het huidige werkgelegenheidsbeleid van het kabinet Kok. Daarna worden de begrippen 'werk' en 'werkloosheid' in een historisch perspectief geplaatst. Vervolgens gaan we na hoe diverse ontwikkelingen de scheiding tussen werk en werkloosheid, en daarmee samenhangende scheiding tussen werk- en niet-werksfeer, ondermijnen. Deze problematiek hangt nauw samen met het ontstaan van een zogenaamd institutioneel vacuüm tussen individuele burger en gemeente, waardoor op dit niveau een dynamische besluitvormingsstructuur ontbreekt. Dit vacuüm kan worden gezien als een fundamentele constructiefout van de Westerse samenleving die zichtbaar wordt in het probleem van structurele werkloosheid, en we bespreken vervolgens de wijze waarop de principes van sociocratisch kringorganiseren 
gebruikt kunnen worden om genoemd vacuüm in te vullen. Tot slot wordt de bijdrage die deze analyse kan leveren aan de discussie over werkloosheid en werkloosheidsbestrijding (door het kabinet Kok) besproken.

Vanzelfsprekend hangt het werkloosheidsvraagstuk nauw samen met het sociale zekerheidsvraagstuk. Deze verwevenheid zal ook in dit artikel regelmatig worden aangekaart. Integrale oplossingsrichtingen voor het sociale zekerheidsvraagstuk zullen hier niet worden besproken, ook omdat deze elders in de literatuur worden aangereikt. ${ }^{1}$

\section{Het huidige werkgelegenheidsbeleid}

De regering Kok heeft een werkgelegenheidsbeleid ontwikkeld dat bestaat uit een vijftal sporen zoals recentelijk samengevat door Van Vliet (1995). Het eerste spoor in dit beleid betreft het macroeconomisch beleid dat gericht is op een verlaging van de belasting- en premiedruk, waardoor de loonkosten voor bedrijven gunstiger worden en de werkgelegenheidsgroei wordt gestimuleerd.

Verder richt het kabinet Kok zich ook op een versterking van de economische structuur, ondermeer via investeringen in de materiële infrastructuur (stadsvernieuwing, wegenbouw en grote infrastructurele projekten zoals de Betuwelijn en uitbreiding van Schiphol) en de vermindering van belemmeringen op produkt- en arbeidsmarkten (op het punt van bij voorbeeld vestiging, winkelsluiting en arbeidstijden).

Het derde spoor betreft de herverdeling van werk. Op dit terrein tracht het huidige kabinet de tendens naar meer deeltijdwerk te bevorderen, regelingen voor zorg- en scholingsverlof uit te breiden teneinde een evenwichtiger verdeling van onbetaald werk tussen mannen en vrouwen te realiseren, en maatregelen ter stimulering van arbeidsduurverkorting te combineren met bedrijfstijdverlenging en flexibilisering van de werkweek (zoals tot uiting komt in recente CAO's van AKZO en KPN).

Het vierde spoor richt zich op het laagste segment van de arbeidsmarkt waar de werkloosheid relatief het grootst is. Vooral het instrument van activering van uitkeringsgelden wordt hiervoor ingezet. Dat wil zeggen dat uitkeringen worden gebruikt om extra banen te scheppen in die sectoren waar nuttig en noodzakelijk werk blijft liggen.

Het laatste aandachtspunt in het beleid van het kabinet Kok is een grootscheepse aanpassing van de belangrijkste bestaande instellingen zoals de arbeidsvoorziening, gemeentelijke sociale diensten en bedrijfsverenigingen. Dit gebeurt onder meer via intensievere samenwerking tussen deze drie soorten instellingen. Daarnaast worden uitkeringsinstellingen zoals de GSD en het GAK getransformeerd naar organisaties die zich bezig houden met uitkeringen én de uitstroom van hun cliënten naar betaald werk, en wordt de arbeidsvoorziening nadrukkelijker geconcentreerd op de bemiddeling van mensen die niet zelfstandig in staat zijn werk te vinden.

Over het geheel genomen is dit werkgelegenheidsbeleid goed doordacht, en lijkt het ook in samenhang met de gunstige ontwikkeling van de internationale conjunctuur van de afgelopen jaren een bijdrage te leveren aan de bestrijding van de werkloosheid. Echter zelfs indien de ambitie van het kabinet Kok - 100.000 banen extra per jaar - 10 jaar wordt volgehouden, leidt dat slechts tot ongeveer een halvering van de geregistreerde werkloosheid die momenteel bestaat uit ongeveer een half miljoen 
mensen (Van Vliet, 1995).

\section{Werk en werkloosheid als sociale constructies}

Historisch gezien kunnen werk en werkloosheid worden beschouwd als zogenaamde sociale constructies die in de loop der tijd zijn ontstaan, mede in het licht van veranderingen in de sociaal-economische context (Piore, 1987; Keyssar, 1986; Salais et al., 1986). Als zodanig zijn werk en werkloosheid tot in het begin van deze eeuw geen duidelijk afgebakende begrippen. Tot de wereldwijde crisis van de jaren dertig was 'werkloosheid' als aanduiding van een categorie personen een uitermate vaag begrip. In de destijds dominante bedrijfstakken - zoals de agrarische sector, handel en kleinschalige ambachtelijke nijverheid - was bedrijfsmatig werk (voor de markt en eigen consumptie), huishoudelijk werk (voor het gezin) en het eventuele verblijf van kinderen op school zodanig met elkaar verweven dat de grens tussen deze activiteiten moeilijk te bepalen was. De steeds wisselende economische en seizoensgebonden omstandigheden noodzaakten frequent tot aanpassingen in de tijdsbesteding aan deze verschillende soorten werk. Op het platteland en in kleine dorpen veranderden de meeste gezinsleden frequent de verdeling van tijd tussen het boerenbedrijf en kleine nijverheidswerkplaatsen (en school voorzover het kinderen betrof). Wanneer er niet voor iedereen voldoende werk was, vielen de betrokkenen veelal terug op ondersteuning door bij voorbeeld gezinsleden die wel werk en daardoor inkomen hadden. Al deze veranderingen werden niet geregistreerd in regionale of landelijke werkloosheidsstatistieken, voorzover aanwezig (Piore, 1987; Salais et al., 1986). Dit geldt in belangrijke mate ook nu nog voor bij voorbeeld meewerkende gezinsleden in agrarische en andere kleine familiebedrijven.

De opkomst van het huidige begrip 'werkloosheid' in de westerse welvaartstaat, in de zin van onvrijwillige ledigheid, valt samen met het ontstaan van grootschalige industriële bedrijvigheid (Keyssar, 1986; Salais, Baverez en Reynaud, 1986). Het werken in grote industriële werkplaatsen en fabriekshallen noodzaakte tot een radicale scheiding in tijd en ruimte tussen gezinsleven en vrije tijd enerzijds en werk anderzijds. De werknemer werkt dagelijks gedurende een vastgestelde periode in een fabriekshal die ondermeer via muren en poorten in ruimtelijk opzicht duidelijk gescheiden is van de buitenwereld. Indien het werk in deze situatie wegvalt, ontstaat onmiddelijk een soort leegte in het leven van de werknemer die zeer scherp als werkloosheid te definiëren valt (zie ook: Habermas, 1970).

De gevolgen van deze leegte zijn meestal dramatisch voor voormalige industriewerknemers, omdat hun vermogen om zelfstandig te handelen wordt ondermijnd door het gestandaardiseerde produktiewerk dat vooral na de tweede wereldoorlog in Nederland en andere landen van de grond kwam. Industrie-arbeiders dienden het tempo van hun werk volledig af te stemmen op dat van machines, terwijl in het pre-industriële tijdperk bij voorbeeld de uitoefening van een ambachtelijk beroep juist veel zelfstandigheid vereiste, zowel wat betreft de planning van het werk als het werk zelf (Pahl, 1992).

De nu gangbare begrippen werk en werkloosheid hebben definitief wortel geschoten in de Westerse samenleving door de opkomst van het collectieve sociale zekerheidstelsel (Salais et al., 1986; Piore, 1987). Tot het begin van deze eeuw werd sociale zekerheid vooral als een lokaal probleem gezien en deels opgelost door middel van ondersteuning van gezinsleden, buren, vakverenigingen, 
ambachtsgilden en liefdadigheid (de bedeling). De enorme uitstoot van personeel tijdens de crisis van de jaren dertig veroorzaakte echter een onhoudbare druk op deze lokale sociale vangnetten, waardoor de overheid min of meer gedwongen werd om in te springen, onder meer door het creëren van werkgelegenheid via grootschalige investeringen in infrastructuur. Vanaf die tijd, en vooral na WO II, begon de overheid in bij voorbeeld Frankrijk, Engeland en Nederland een sociaal zekerheidssysteem te ontwikkelen dat is gebaseerd op een scherpe afbakening tussen werk en werkloosheid. Deze afbakening maakte financiering van sociale zekerheid door middel van collectieve premie- en belastingheffing mogelijk, wat de facto leidt tot collectieve inkomensoverdrachten van werkenden naar niet-werkenden.

Al met al was werk in de pre-industriële periode dus een veel omvattend begrip en werkloosheid een weinig omvattend of zelfs bijna leeg begrip. Door de opkomst van industriële werkgelegenheid en collectieve sociale zekerheidsystemen wordt de definitie van werk gaandeweg beperkt tot een veel kleinere categorie van activiteiten die in tijd en ruimte duidelijk te onderscheiden zijn van huishoudelijke, recreatieve en andere bezigheden. Werkloosheid wordt vanaf dat moment eenduidig gedefinieerd als onvrijwillige ofwel niet-verwijtbare ledigheid. Deze definitie van werkloosheid vormt tot op de dag van vandaag een centraal uitgangspunt voor overheidsbeleid op het terrein van werkloosheid en sociale zekerheid (Kooijman, 1995; van Vliet, 1995). ${ }^{2}$

Daarmee wordt ook duidelijk dat een belangrijke peiler van het huidige Nederlandse sociaaleconomisch bestel bestaat uit

een strikte scheiding tussen werk en onvrijwillige werkloosheid, en de daarmee samenhangende scheiding tussen werksfeer en niet-werksfeer, die met name in de industriële sector ontstaan en aanwezig is, en

(c) die financiering van de sociale zekerheid via collectieve premie- en belastingheffing mogelijk maakt.

Deze collectieve verwevenheid tussen werkgelegenheid en sociale zekerheid staat in schril contrast met de relatief losse relatie tussen beide vraagstukken in de pre-industriële wereld waarin de verbinding tussen het economische en het sociale vooral als een lokaal probleem werd benaderd.

\section{Ondermijning van scheiding tussen werk en werkloosheid}

We hebben zojuist vast gesteld dat het moderne begrip werkloosheid in hoge mate is gebaseerd op een strikte scheiding tussen de werk- en niet-werksfeer. Een dergelijke scheiding heeft merkwaardige implicaties. Indien een hoogleraar een boek leest is dat werk, maar wanneer zij in de tuin werkt is dat vrije tijdsbesteding of hobby. Voor de tuinman geldt echter precies het omgekeerde. Wanneer huishoudelijke klussen zoals schoonmaken en koken gedaan worden door gezinsleden, wordt dit eerder als vrijetijdsbesteding dan als werk gezien, maar indien dezelfde klussen worden verricht door een betaalde huishoudelijke hulp is plotseling wel sprake van werk.

De scheiding tussen werk- en niet-werksfeer, als belangrijke peiler onder het Nederlands sociaaleconomisch bestel, wordt al geruime tijd door twee ontwikkelingen ondermijnd: de afkalving van de werkgelegenheid in de industriële sector enerzijds, en de aanzuigende en inefficiënte werking van de 
sociale zekerheid anderzijds.

De snelle groei van de werkgelegenheid in de dienstverlenende en publieke sector, heeft de afkalving van de werkgelegenheid in de industriële sector lange tijd kunnen compenseren, maar ondermijnt tegelijkertijd de scherpe afbakening tussen werk- en niet-werksfeer. In de dienstverlenende sector zijn bij voorbeeld veel kleine bedrijven werkzaam die vanuit de eigen woning opereren, en waarin de steeds wisselende economische omstandigheden tot frequente aanpassingen in tijdsbesteding leiden. Ook is in vooral de dienstverlenende sector sprake van de opkomst van bij voorbeeld projectwerk, thuiswerk, freelancewerk en telewerk waardoor de grens tussen de privé- en de werkomgeving steeds meer vervaagt.

De tweede soort bedreiging vloeit voort uit de gestage groei van het aantal 'niet-werkenden' ten opzichte van het aantal 'werkenden', volgens de gangbare definities van deze categorieën. Deze scheefgroei is met name een gevolg van de aanzuigende werking van de sociale zekerheid, die op zijn beurt deels wordt veroorzaakt door het verschijnsel van uitkeringsafhankelijkheid: hiermee wordt bedoeld dat het sociale zekerheidssysteem bestendiging van de uitkeringssituatie in hoge mate blijkt te bevorderen (Murray, 1984; Veenman en Verburg, 1994; van Geuns en Homburg, 1994). De scheefgroei tussen niet-werkenden en werkenden leidt tot een financieel probleem, door sommigen zelfs gezien als een 'sociale tijdbom' (Eijspaart, 1995), in de vorm van te hoge lasten voor het werkende deel van de bevolking. Paradoxaal genoeg lag de ontwikkeling van het systeem van collectieve sociale zekerheid destijds ten grondslag aan het definitief wortel schieten van het industriële begrip van werk, terwijl de financiële consequenties van het sociale zekerheidsysteem nu deze peiler van het sociaal-economisch bestel ondergraven.

\section{Het institutionele vacuüm tussen burger en gemeente}

Op basis van het voorafgaande betoog kunnen we concluderen dat werkloosheid vanuit een historisch oogpunt geen vast omlijnd begrip vormt, maar via een aantal met elkaar samenhangende collectieve keuzes en ontwikkelingen is geconstrueerd. Dit is zeker geen geruststellende conclusie, maar het verschaft wel uitzicht op een meer fundamentele aanpak van het vraagstuk van werkloosheid. Een terugkeer naar pre-industriële sociale structuren is wat dit betreft onmogelijk en ook (gelukkig) niet nodig, maar in deze structuren ligt wel een deel van het antwoord.

Op het niveau van de gemeente, regio en rijksoverheid is een uitgebreid netwerk van beleidsvoorbereidende, adviserende en uitvoerende organisaties ontstaan die werkzaam zijn op het terrein van werkgelegenheidsbeleid, arbeidsbemiddeling, en dergelijke (van der Zwaan, 1985). Tussen het gemeentelijk niveau en de individuele burger bestaat echter vrijwel geen enkele systematisch ingerichte sociaal-politieke structuur. Door het wegvallen van de traditionele lokale vangnetten (familie, kerk, gilde, en dergelijke) is zelfs gaandeweg een zogenaamd institutioneel vacuüm ontstaan. ${ }^{3}$ Dit vacuüm betreft vooral een gebrek aan overlegorganen en sturingsmiddelen die de kloof tussen burger en vooral de middelgrote en grote gemeenten kunnen dichten. De ontwikkeling van dit vacuüm is versterkt door de huidige tendens naar het verdwijnen van diverse centrale instituties in de Nederlandse arbeidsverhou- 
dingen (Nagelkerke, 1994), zonder dat institutionele vernieuwing op het decentrale niveau van bedrijven, instellingen, buurten en wijken de ontstane leegte heeft opgevuld.

Het institutionele vacuüm zien we ook terug in de leegte die veel mensen ervaren wanneer ze in een werkloosheidssituatie terecht komen. Deze leegte is latent aanwezig indien men werk heeft, maar wordt zichtbaar en voelbaar indien dit werk wegvalt. Vooral na langdurige gewenning aan de vaste structuur van werk is vaak sprake van een fysiek en sociaal isolement. In dit vacuüm kunnen allerlei relatief onbeheersbare processen met ongewenste effecten hun gang gaan, zoals bij voorbeeld:

- het al eerder genoemde verschijnsel van toenemende uitkeringsafhankelijkheid waardoor bestendiging van de werkloosheidssituatie plaats vindt (Murray, 1984; Veenman en Verburg, 1994; van Geuns en Homburg, 1994);

- de binding met de werkloosheidssituatie wordt ook versterkt door overlevingsstrategieën die gericht zijn op werk in de informele economie (Delsen, 1988; Pahl, 1992);

- naarmate de werkloosheidssituatie voortduurt, neemt de kans toe dat men gaat berusten in zijn lot en niet meer investeert in zijn of haar sociale kapitaal (het geheel aan contacten dat iemand onderhoudt) waardoor ook de terugkeer naar een betaalde baan steeds onwaarschijnlijker wordt (Flap et al., 1987; Mevissen en Renooy, 1987);

- individuele uitkeringstrekkers wekken de afgunst van de participant in de formele economie die "ergens in een file met verlangen terugdenkt aan zijn warme bed en de 'profiteur' verfoeit die zich nog eens lekker omdraait" (Glebbeek, 1996: p. 357);

- het misbruik van sociale zekerheidsregelingen is moeilijk op te sporen en te voorkomen (Kooijman, 1995).

Deze en andere ongewenste processen kunnen ongehinderd hun gang gaan, met name omdat op het lokale niveau van wijken en buurten geen middelen voorhanden zijn om deze processen zichtbaar te maken en te corrigeren. Bovendien zijn werkgelegenheid en collectieve sociale zekerheid zodanig met elkaar verweven geraakt dat elke ingreep in het ene deelsysteem een (ex ante) onvoorspelbare doorwerking heeft in het andere deelsysteem. Ook valt op dat de barrières die zijn opgebouwd tussen werk- en niet-werksfeer in de context van het genoemde vacuüm een uitermate nadelige invloed lijken uit te oefenen. Wat dit betreft zijn diverse eerder genoemde ontwikkelingen in de werkloosheidssituatie, zoals toenemende uitkeringsafhankelijkheid en afnemende investering in sociaal kapitaal, over het algemeen niet gunstig voor een terugkeer in de formele economie.

\section{Het belang van lokaal initiatief}

De vraag is nu of de doeltreffendheid van werkloosheidsbeleid kan toenemen indien het genoemde vacuüm tussen individu en gemeente wordt opgevuld. Het is in dit verband opmerkelijk dat incidentele lokale initiatieven in verschillende Nederlandse steden, bij voorbeeld onder de noemer van integraal wijkbeheer, hebben geleid tot een plaatselijke vermindering van vandalisme en kleine criminaliteit en een aanmerkelijke vergroting van de veiligheid in openbare ruimten zoals kinderspeelplaatsen, parken 
en winkelcentra; deze initiatieven zijn veelal door de inzet van eigen bewoners gerealiseerd (Sociaal Cultureel Planbureau, 1994).

Dit soort relatief spontane initiatieven dienen eigenlijk een veel belangrijkere rol te spelen, en staan in schril contrast met recente pogingen in Amsterdam en Rotterdam om de besluitvorming dichter naar de burgers toe te brengen, waaraan diezelfde burgers vervolgens massaal weigerden mee te werken. Het contrast tussen het potentieel aan zelforganiserend vermogen van burgers in wijken en buurten enerzijds en dergelijke tot mislukken gedoemde pogingen van de overheid om de kloof met de burger te dichten anderzijds laten zien dat het invullen van het institutionele vacuüm tussen burger en gemeente dient te gebeuren op basis van twee uitgangspunten. Ten eerste, moet er sprake zijn van besluitvormingsprocessen waarin de eigenheid en zeggenschap van alle betrokkenen wordt gewaarborgd. Ten tweede dienen de verschillende beleidsniveaus met elkaar verbonden worden op een manier die garandeert dat macht en informatie even makkelijk van burger naar de gekozen gemeentelijke vertegenwoordigers vloeit, als van gemeente naar de burger. Met andere woorden, de gemeentelijke democratie en hiërarchie moeten met elkaar in evenwicht zijn.

\section{Kringprocessen tussen burger en gemeente}

De Rotterdamse ingenieur en ondernemer Gerard Endenburg ontwikkelde al in de jaren zeventig een concrete oplossing voor het vacuüm tussen burger en gemeente die aan de zo juist genoemde voorwaarden voldoet. De zogenaamde sociocratische organisatiemethode van Endenburg wordt momenteel vooral toegepast in de particuliere sector (Reijmer en Romme, 1996) maar is ook van toepassing op het opnieuw vormgeven van besluitvorming in de (lokale) collectieve sector. Endenburg (1981) beschrijft de wijze waarop het vacuüm tussen burger en gemeente kan worden ingevuld door middel van buurt- en wijkkringen. Deze kringen nemen beslissingen op basis van gelijkwaardigheid, wat concreet betekent dat iedere deelnemer het recht heeft om een beargumenteerd bezwaar te maken. De buurtkringen zijn gekoppeld aan de wijkkring door middel van een tweeledige verbinding: ten eerste iemand die de werkzaamheden van de betreffende buurtkring coördineert, en daarnaast minimaal één persoon die als gekozen vertegenwoordiger van de buurtking deelneemt in de wijkkring. De verbinding tussen wijkkring en gemeente wordt op analoge wijze gelegd: dat wil zeggen dat in de gemeentekring (ofwel de huidige gemeenteraad) zowel wijkcoördinatoren als gekozen wijkvertegenwoordigers zitting hebben, in dit geval samen met de burgemeester en wethouders die de leidinggevende en coördinerende functie in de gemeentekring vervullen. In figuur 1 wordt deze kringstructuur schematisch weergegeven. Het aantal buurtkringen dat aan een wijkkring kan worden gekoppeld kan per situatie verschillen, maar gedacht moet worden aan buurten van elk ongeveer 80 volwassen burgers die onderdeel uitmaken van een wijk die uit ongeveer 15 tot 20 buurten bestaat. In de grotere gemeente zal het derhalve nodig zijn om een extra kringniveau tussen te voegen, bij voorbeeld dat van de deelgemeente.

Deelname in de bijeenkomsten van de buurtkring door buurtbewoners gebeurt op vrijwillige basis. Dat wil zeggen dat leden van de buurtkring vrij zijn in hun keuze om (nu) niet mee te doen, zonder dat 
dit ten koste gaat van de mogelijkheid om later alsnog in te stappen. Met andere woorden, er staat als het ware altijd een stoel klaar voor elke buurtbewoner (Endenburg, 1981). Deze vrijheid geldt natuurlijk in veel mindere mate voor bij voorbeeld die leden van een buurtkring die als vertegenwoordiger in de wijkkring worden gekozen.

FIGUUR 1 hier plaatsen

Experimenten met buurt- en wijkkringen in de Rotterdamse wijk Charlois hebben laten zien dat een dergelijke aanpak vrijwel meteen effekt sorteert, zelfs indien de koppeling tussen wijkniveau en gemeente achterwege blijft. In korte tijd werden in deze wijk door de bewoners zelf een groot aantal behoeften in kaart gebracht, onder andere met betrekking tot vernield straatmeubilair, kleine criminaliteit, onveilige verkeerssituaties en het gebrek aan economische bedrijvigheid. Dit leidde tot een aanzienlijke hoeveelheid betaald werk voor wijkbewoners, bij voorbeeld in de vorm van het opknappen van straatmeubilair, het verbeteren van onveilige verkeerssituaties en de start van verschillende bedrijven (Houdijk, 1993).

Dergelijke experimenten wijzen ook op het belang van institutionele vernieuwing "van onder op", dat wil zeggen vanuit de buurten en wijken. Dat betekent ook dat juist daar waar al eerder op lokaal niveau een gebrek aan overleg- en besluitvormingsstructuren door de betrokken bewoners is vast gesteld, experimenten met kringstructuren de meeste kans van slagen hebben.

\section{Werkloosheid en het institutionele vacuüm}

Volgens Endenburg (1995) verwijst werkloosheid eigenlijk naar een fundamentele constructiefout in de moderne Westerse samenleving, namelijk het ontbreken van een dynamische sociaal-politieke structuur die ons in staat stelt werk te genereren. Wat dit betreft bestaat in Nederland een indrukwekkend netwerk van instituties voor de verdeling van werk en inkomen, met name op gemeentelijk, regionaal en landelijk niveau (Nagelkerke, 1994) maar is tussen burger en gemeente sprake van het eerder beschreven vacuüm.

Endenburg omschrijft werk als activiteiten waarmee we proberen te voldoen aan behoeften, en keert daarmee nadrukkelijk terug naar het primaire begrip werk dat direkt gekoppeld is aan behoeften als de generator van werk. Illich beschreef al eerder de gevolgen van industrialisatie en massaconsumptie op de plaats die we zijn gaan toekennen aan behoeften. Volgens Illich zien we tegenwoordig de produktie van consumptiegoederen en dienstverlening in het centrum van het economisch systeem en relateren we onze behoeften uitsluitend aan dit centrum (Illich, 1978). Campbell (1987) noemt dit de 'geest van het consumentisme' die vooral zichtbaar is in de centrale rol van allerlei vormen van reclame. Voor het steeds weer opnieuw scheppen van werkgelegenheid is volgens Endenburg (1981) een omkering in de relatie tussen produktie en behoeften noodzakelijk. Dat wil zeggen dat productieve activiteiten dienen te ontstaan vanuit individuele en collectieve behoeften. Dit uitgangspunt lijkt een open deur, maar staat wel in schril contrast met de wijze waarop de cultuur van het consumentisme is doorgedrongen in het 
dagelijkse leven en de eigen identiteit van individuele burgers dreigt te ondermijnen (Campbell, 1987; Lunt en Livingstone, 1992).

Door het ontstaan van het institutionele vacuüm, ontstaat het gevaar dat veel behoeften die niet direkt passen in het aangeboden repertoire van produkten en diensten onzichtbaar blijven, en dus ook niet als generator van werkgelegenheid kunnen fungeren. Veel behoeften blijven in deze situatie derhalve latent, en daarmee blijft een belangrijke bron van werkgelegenheidsgroei onbenut. Het adequaat invullen van het vacuüm tussen burger en gemeente vormt dus wellicht een belangrijke voorwaarde voor het steeds weer opnieuw kunnen creëren van werkgelegenheid.

Werkloosheid verwijst derhalve naar een dieperliggend probleem, namelijk het ontbreken van een sociaal-politieke structuur waarin iedere burger een plek heeft van waar uit hij een identiteit als actief en betrokken lid van de samenleving kan verwerven, en waarin ondernemerschap en werkgelegenheidsgroei wordt gestimuleerd door onvervulde individuele en collectieve behoeften. De oplossing die door Endenburg wordt aangereikt vormt geen pleister op de wond, maar is gericht op een structurele invulling van het institutionele vacuüm dat in westerse samenlevingen op lokaal niveau geleidelijk is ontstaan. De analyse en oplossing van Endenburg is zeker niet volledig en wellicht ook niet de enigst mogelijke, maar kan in de huidige discussie over werkloosheid en werkloosheidsbeleid wel een nieuw gezichtspunt opleveren.

\section{Tot slot}

De visie van Endenburg omvat een verassende zienswijze op de tegenstelling tussen werk en werkloosheid, en de daaraan voorafgaande scheiding tussen werk- en privésfeer. Door een fundamentele herbezinning op de rol van de niet-werksfeer als bron van werkgelegenheid, kan ook het relatieve falen van het huidige instrumentarium voor werkloosheidsbestrijding in een ander daglicht komen te staan. In ieder geval verdient de volgende hypothese nader onderzoek: bestaande instrumenten om werkgelegenheid te bevorderen en werkloosheid te verminderen sorteren meer effekt indien ze zijn ingebed in een lokale infrastructuur waarin informatie even makkelijk van de burger naar de gemeente (en rijksoverheid) stroomt, als andersom. Het werkgelegenheidsbeleid van het kabinet Kok is, zoals we eerder in dit artikel hebben vastgesteld, goed doordacht en lijkt ook de geregistreerde werkloosheid in niet geringe mate te verminderen. De doeltreffendheid van dit beleid zou echter in hoge mate kunnen toenemen indien kringprocessen in buurten en wijken als lokale werkgelegenheidsgeneratoren gaan functioneren. In dit opzicht lijkt het beleid van het kabinet Kok in hoge mate complementair aan de kringorganisatie-methode als oplossing voor het vacuüm tussen burger en gemeente.

Behoudens een enkel experiment in Rotterdam is nog weinig bekend over de te verwachten resultaten van deze oplossingsrichting. Tegen deze achtergrond is in dit artikel vooral een beroep gedaan op het 'gezond verstand' van de lezer, met name door het werkloosheidsvraagstuk in een breder historisch kader te plaatsen. Voortbouwend op de ervaringen die ook met bij voorbeeld integraal wijkbeheer zijn opgedaan, zullen gerichte experimenten met kringprocessen tussen burger, buurt, wijk 
en gemeente moeten uitwijzen hoeveel direkte en indirekte werkgelegenheid hierdoor kan worden gecreërd. Op deze wijze kan de zo juist opgeworpen hypothese worden getoetst.

Analoog aan de ervaringen die met de sociocratische kringmethode zijn opgedaan in een groot aantal ondernemingen en instellingen (Reijmer en Romme, 1996), verminderen de kringprocessen op het niveau van buurten, wijken en gemeenten wellicht ook de demotiverende invloed die de kloof tussen burger en overheid nu op beide partijen heeft. 
1. In het algemeen onderkent men de noodzaak om de negatieve invloed van het sociale zekerheidssysteem op het economisch systeem op te heffen of in ieder geval te verminderen. Het bestaande sociale zekerheidssysteem verstoort in hoge mate de werking van het economische systeem dat gericht is op ruil tussen vragers en aanbieders, waardoor aan bestaande of nieuwe behoeften kan worden voldaan. Sociale zekerheid heeft betrekking op het creëren van inkomenszekerheid (via het reserveren van een deel van het huidige inkomen voor later gebruik), wat in principe mogelijk is zonder een schadelijke uitwerking op het economische systeem (bestaande uit transacties tussen 'werk' en 'behoefte'). Dit kan bijvoorbeeld via een soort basisinkomen, maar ook via een stelsel van particuliere en collectieve verzekeringen waardoor geen uitkeringsafhankelijkheid ontstaat (Glebbeek, 1996; van den Heuvel, 1988; Roebroek en Hogenboom, 1990).

2. Werkloosheid als onvrijwillige non-activiteit vormt ook het uitgangspunt voor economen die het werkloosheidsvraagstuk onderzoeken (Lindbeck, 1994; Pen, 1992).

3. Het begrip 'institutioneel vacuüm' is ontleend aan Beaumont (1995) die een vergelijkbare ontwikkeling beschrijft in de Britse situatie. 


\section{Bronnen}

Beaumont, P.B. (1995), The Future of Employment Relations. London, Sage.

Campbell, C. (1987), The Romantic Ethic and the Spirit of Modern Consumerism. Oxford/New York, Basil Blackwell.

Delsen, L. (1988), 'Deeltijdarbeid en informele economie', Tijdschrift voor Arbeidsvraagstukken, 4, nr. 1: p. 37-46.

Endenburg, G. (1981), Sociocratie: Het Organiseren van de Besluitvorming. Alphen a.d. Rijn, Samson.

Endenburg, G. (1992), Sociocratie als Sociaal Ontwerp. Delft, Eburon.

Endenburg, G. (1995), Zorgzaam Ondernemen, bijdrage aan congres over Werkloosheidsvraagstuk, georganiseerd door Sociocratisch Centrum Nederland, Utrecht, november 1995.

Eijspaart, T. (1995), 'Sociale tijdbom', PW Personeelsmanagement, 23 september 1995, p. 12-14.

Flap, H., N. Lam, M. Sprengers \& F. Tazelaar (1987), 'Netwerken en werkloosheid', Tijdschrift voor Arbeidsvraagstukken, vol. 3, nr. 3: p. 69-79.

Freeman, R.B. (1995), 'The large welfare state as a system', American Economic Review, AEA Papers and Proceedings, vol. 85, no. 2, p. 16-21.

Geuns, R. van \& G. Homburg (1994), 'De uitvoering van de bijstandswet', Tijdschrift voor Arbeidsvraagstukken, vol. 10, 209-219.

Glebbeek, A.C. (1996), 'Werkloosheid en sociaal beleid: Op zoek naar nieuwe instituties', Tijdschrift voor Arbeidsvraagstukken, vol. 51, 347-358.

Habermas, J. (1970), Arbeit, Erkenntnis, Fortschritt, Amsterdam, De Munter.

Heuvel, F.G. van den (1988), 'Structurele sociale zekerheidsproblemen nu en in de toekomst', Sociaal Maandblad Arbeid, vol. 43: p. 58-63.

Houdijk, J. (1993), 'Als de buurt weer van de mensen wordt', Argumenten, vol. 14, nr. 4 (oktober): p. 813.

Illich, I. (1978), Het Recht op Nuttige Werkloosheid (vert. van: The right to useful unemployment). Baarn, Het Wereldvenster.

Keyssar, A. (1986), Out of Work: The First Century of Unemployment in Massachussets. Cambridge, Cambridge University Press.

Kooijman, J.J.A. (1995), 'Verwijtbaaar werkloos? Naar de bijstand!', Sociaal Maandblad Arbeid, vol. 50: p. 493-509.

Lindbeck, A. (1994), 'The welfare state and the employment problem', American Economic Review, AEA Papers and Proceedings, vol. 84, no. 2, p. 71-75.

Lunt, P.K. en S.M. Livingstone (1992), Mass Consumption and Personal Identity. Buckingham, Open University Press.

Mevissen, J.W.M. en P.H. Renooy (1987), 'De economie van het dagelijks leven. De betekenis van sociale netwerken voor de informele economie', Tijdschrift voor Arbeidsvraagstukken, vol. 3, nr. 2: p. 516. 
Murray, C. (1984), Losing Ground: American Social Policy 1950-1980, New York, Basic Books.

Nagelkerke, A.G. (1994), 'Institutioneel balanceren', Sociaal Maandblad Arbeid, vol. 49: p. 20-30.

Pahl, R.E. (1992), 'Does jobless mean workless? A Comparative approach to the survival strategies of unemployed people', in: C.H.A. Verhaar \& L.G. Jansma (eds.), On the Mysteries of Unemployment: Causes, Consequences and Policies, p. 209-223. Dordrecht, Kluwer.

Pen, J. (1992), 'Unemployment as a mystery', in: C.H.A. Verhaar \& L.G. Jansma (eds.), On the Mysteries of Unemployment: Causes, Consequences and Policies, p. 25-31. Dordrecht, Kluwer.

Piore, M.J. (1987), 'Historical Perspectives and the Interpretation of Unemployment', Journal of Economic Literature, vol. 25, p. 1834-1850.

Reijmer, J.M. en A.G.L. Romme (1996), 'Sturing en zelforganisatie volgens sociocratische principes', Argumenten, vol. 17, nr. 1, p. 9-18.

Roebroek, J.M. en E. Hogenboom (1990), Basisinkomen: Alternatieve Uitkering of Nieuw Paradigma?, 's-Gravenhage, Commissie Onderzoek Sociale Zekerheid.

Romme, A.G.L. (1995), 'Non-participation and system dynamics', System Dynamics Review, vol. 11, p. 311-319.

Salais, R., N. Baverez en B. Reynaud (1986), L'Invention du Chômage: Histoire et Transformations d'une Catégorie en France des Années 1890 aux Années 1980. Paris, Presses Universitaires de France.

Sociaal Cultureel Planbureau (1994), Evaluatie sociale vernieuwing: het eindrapport, Den Haag, VUGA.

Veenman, J. \& R. Verburg (1994), 'De uitstroom van Surinamers uit de GSD-bestanden:

belemmeringen binnen de organisatie', Tijdschrift voor Arbeidsvraagstukken, vol. 10, p. 220-227.

Vliet, G.E. van (1995), Werkgelegenheidsbeleid van kabinet Kok sociocratisch bezien, bijdrage aan congres over Werkloosheidsvraagstuk, georganiseerd door Sociocratisch Centrum Nederland, Utrecht, november 1995.

Weitzman, M.L. (1984), The Share Economy, Cambridge, Harvard University Press.

Wijvekate, M.L. \& F.P. Wijvekate (1983), Alle Hens Aan Dek: Een Nieuw Sociaal-Fiscaal Systeem, Naarden, Strengholt.

Zwaan, A.H. van der (1985), Industriële Verhoudingen in Nederland. Assen, Van Gorcum. 


\section{Over de auteur}

Dr. A.G.L. Romme is verbonden als universitair hoofddocent aan de vakgroep

Managementwetenschappen van de Faculteit der Economische Wetenschappen en Bedrijfskunde, Universiteit Maastricht, en geeft tevens leiding aan de afdeling Verandermanagement van NIBOR, Netherlands Institute for Business and Organization Research. 